IJIS $\mid$ Indonesian Journal on Information System

\title{
SISTEM INFORMASI KREDIT PEGAWAI PADA PRIMER KOPERASI KARTIKA BABULLAH KOTA TERNATE
}

\section{EMPLOYEES CREDIT INFORMATION SYSTEM IN PRIMARY COOPERATION KARTIKA BABULLAH TERNATE CITY}

\author{
Meirani Khoirotunnisa Effendy ${ }^{1}$, Syahril Hasan ${ }^{2}$ \\ Program Studi Komputerisasi Akuntansi, \\ Politeknik Sains dan Teknologi Wiratama Maluku Utara \\ meirani_khoirotunnisa@gmail.com
}

\begin{abstract}
Abstrak
Primer Koperasi Kartika Babullah Kota Ternate merupakan suatu wadah usaha yang bergerak pada koperasi simpan pinjam. Pemberian kredit merupakan suatu usaha koperasi yang paling pokok, maka koperasi perlu memberikan penilaian terhadap nasabah yang mengajukan kredit pinjaman serta merasa yakin bahwa nasabahnya tersebut mampu untuk mengembalikan kredit yang telah diterimanya. Selain itu sistem yang digunakan pada Primer Koperasi Kartika Babullah Kota Ternate masih menggunakan sistem simpan pinjam yang manual, dimana semua pencatatan dilakukan dalam buku dokumen, sehingga sering dijumpai adanya kesalahan yang disebabkan oleh kurang telitinya dalam perhitungan serta kemungkinan terjadinya proses yang sangat lama dalam kegiatan koperasi tersebut, apalagi data yang diolah cukup banyak akan berpengaruh pada efisiensi waktu dan tenaga, Sistem yang dirancang menggunakan Aplikasi Borland Delphi 7, adanya aplikasi ini para anggota koperasi dapat dengan mudah menginput daftar pinjaman anggota, pengembalian pinjaman anggota dan juga semua hal yang menyangkut pengolahan data perkreditan pegawai dengan begitu dapat membantu nasabah mendapatkan informasi yang dibutuhkan dengan mudah
\end{abstract}

Kata Kunci : Sistem Informasi, Kredit, Koperasi

\begin{abstract}
Primary Cooperative Kartika Babullah Ternate is a container business that engaged in savings and credit cooperatives. Giving credit is a cooperative effort of the most basic, the cooperative needs to provide an assessment of the customers who apply for credit loan and feel confident that their customers are able to repay the loan he had received. In addition the system used on the Primary Cooperative Kartika Babullah Kota Ternate still use the savings and loan system is manual, where all the recording was done in the book document, so often encountered an error caused by a lack of precision as in the calculation as well as the possibility of a very long process in cooperative activities that, especially the processed data is pretty much going to affect the efficiency of time and energy, The system designed using Borland Delphi 7 Application, this application cooperative members can easily enter a list of member loans, loan repayment members, as well as all matters relating to data processing credit clerks doing so, can help customers obtain the required information easily
\end{abstract}

Keyword: Information System, Credit, Cooperation 


\section{PENDAHULUAN}

Seiring dengan berkembangnya teknologi informasi yang semakin pesat, peran teknologi informasi dan komunikasi di era globalisasi saat ini benar-benar telah memberikan pengaruh yang cukup besar, hampir disemua sektor telah merasakan sinergitas terhadap penggunaanya. Pendidikan, koperasi, kedokteran, pemerintahan, militer, transportasi, organisasi, dan lain sebagainya telah menjadi bukti pelopor dalam pengembangan kemajuan teknologi informasi ditengah kebutuhan manusia yang kian hari kian meningkat

Primer Koperasi Kartika Babullah Kota Ternate merupakan suatu wadah usaha yang bergerak pada koperasi simpan pinjam. Pemberian kredit merupakan suatu usaha koperasi yang paling pokok, maka koperasi perlu memberikan penilaian terhadap nasabah yang mengajukan kredit pinjaman serta merasa yakin bahwa nasabahnya tersebut mampu untuk mengembalikan kredit yang telah diterimanya. Selain itu sistem yang digunakan pada Primer Koperasi Kartika Babullah Kota Ternate masih menggunakan sistem simpan pinjam yang manual, dimana semua pencatatan dilakukan dalam buku dokumen, sehingga sering dijumpai adanya kesalahan yang disebabkan oleh kurang telitinya dalam perhitungan serta kemungkinan terjadinya proses yang sangat lama dalam kegiatan koperasi tersebut, apalagi data yang diolah cukup banyak akan berpengaruh pada efisiensi waktu dan tenaga. Masalah keamanan atas kredit yang diberikan merupakan masalah yang harus diperhatikan oleh koperasi, karena adanya resiko yang timbul dalam sistem pemberian kredit. Permasalahan ini bisa dihindari dengan adanya suatu pengendalian intern yang dapat menunjang efektivitas sistem pemberian kredit dengan menggunakan aplikasi yang terkomputerisasi. Seperti Borlan Delphi 7, adanya aplikasi ini para anggota koperasi dapat dengan mudah menginput daftar pinjaman anggota, pengembalian pinjaman anggota dan juga semua hal yang menyangkut pengolahan data perkreditan pegawai dengan begitu dapat membantu nasabah mendapatkan informasi yang dibutuhkan dengan mudah

\section{Rumusan Masalah}

Berdasarkan latar belakang di atas, maka rumusan masalah dalam penelitian ini adalah "Bagaimana merancang Sistem Informasi Perkreditan Pegawai Pada Primer Koperasi Kartika Babullah Kota Ternate ? peneiltian ini dibatasi yaitu sistem yang dirancang hanya pada pengolahan data pinjaman, agar mempermudah pegawai kredit dalam mengelola data pinjaman, sehingga bermanfaat bagi manajemen serta pimpinan koperasi sebagai bahan adminstrasi dan pelaporan guna meningkatkan kualitas pelayanan kepada masyarakat

\section{LANDASAN TEORI}

\section{Defenisi Sistem}

Sistem adalah suatu himpunan dari berbagai bagian yang saling berhubungan secara terorganisasi berdasar fungsifungsinya, menjadi suatu kesatuan (Hartono, 2013:10). Dari pembahasan di atas dapat disimpulkan bahwa, Sistem merupakan kumpulan dari elemen-elemen yang berinteraksi untuk mencapai suatu tujuan tertentu, contoh umum misalnya seperti negara. Negara merupakan suatu kumpulan dari beberapa elemen kesatuan lain seperti provinsi yang saling 
berhubungan sehingga membentuk suatu negara dimana yang berperan sebagai penggeraknya yaitu rakyat yang berada dinegara tersebut

\section{Pengertian Informasi}

Informasi adalah data-data yang telah diolah sehingga dapat berguna bagi siapa saja yang membutuhkan. Informasi dapat direkam atau dikirim. Para ahli memiliki banyak arti lain tentang informasi. Informasi bisa dikatakan sebagai pengetahuan yang didapatkan dari belajar, pengalaman atau instruksi. Namun, istilah ini memiliki banyak arti tergantung pada konteksnya.

Pengertian Informasi Menurut kusrini (2007:13), "Informasi dapat didefinisikan sebagai hasil dari olahan data menjadi sebuah bentuk yang bermakna yang digunakan untuk pengambilan keputusan" Pengertian Informasi Menurut Bodnar, (2000: 1), "Informasi adalah data yang diolah sehingga dapat dijadikan dasar untuk mengambil keputusan yang tepat”.

\section{Sistem Informasi}

Menurut Jogiyanto (2005: 18), "Sistem informasi adalah suatu sistem di dalam suatu organisasi yang mempertemukan kebutuhan pengolahan transaksi harian, mendukung operasi, bersifat manajerial dan kegiatan strategi dari suatu organisasi dan menyediakan pihak luar tertentu dengan laporan-laporan yang diperlukan." Menurut Azar Susanto (2007:17), "Sistem informasi merupakan kumpulan dari subsistem apapun baik phisik ataupun nonphisik yang saling berhubungan satu sama lain dan bekerja sama secara harmonis untuk mencapai suatu tujuan yaitu mengolah data menjadi informasi yang berarti dan berguna

\section{Pengertian Data}

Menurut Sayid Syekh (2011:13) menyatakan bahwa data adalah bentuk jamak dari datum. Data merupakan keterangan-keterangan mengenai suatu hal, dapat berupa sesuatu yang diketahui atau dianggap atau anggapan. Agar data dapat berarti dan berguna dalam bentuk informasi maka data perlu di olah melalui suatu model menjadi informasi,penerima kemudiaan menerima informasi tersebut,membuat suatu keputusan dan melakukan tindakan yang menghasilkan suatu tindakan lain yang akan membuat sejumlah data kembali lewat suatu model membentuk siklus informasi.

\section{Pengertian Pengolahan Data}

Pengolahan data (data processing) dapat dikatakan sebagai susunan atau kumpulan dari hasil kegiatan pikiran dengan bantuan tenaga atau suatu peralatan, sehingga dapat menghasilkan informasi untuk mencapai tujuan tertentu. Menurut Jogiyanto (2006:9) pengolahan (processing) adalah proses data yang diolah melalui suatu model menjadi informasi, penerima kemudian menerima informasi tersebut, membuat suatu keputusan dan melakukan tindakan, yang berarti menghasilkan suatu tindakan yang lain yang akan membuat sejumlah data kembali. Data tersebut akan dtangkap sebagai input, diproses kembali lewat suatu model dan seterusnya membentuk suatu siklus. Siklus ini disebut juga dengan siklus pengolahan data (data processing cycles).

\section{Pengertian Koperasi}

Koperasi adalah badan hukum yang berdasarkan atas asa kekeluargaan yang anggotanya terdiri dari perorangan atau badan hukum dengan tujuan untuk 
mensejahterakan anggotanya. Umumnya koperasi dikendalikan secara bersama oleh seluruh anggotanya, dimana setiap anggota memiliki hak suara yang sama dalam setiap keputusan yang diambil koperasi. Pembagian keuntungan koperasi biasa disebut sisa hasil usaha atau SHU biasanya dihitung berdasarkan andil. Menurut Samuelson (2005:9), ilmu ekonomi adalah studi tentang perilaku masyarakat dalam menggunakan sumber daya yang langka dalam memproduksi berbagai komoditas, untuk kemudahan menyalurkan kepada berbagai individu dan kelompok yang ada dalam suatu masyarakat. Masyarakat disini terdiri dari sekumpulan produsen, pedagang, dan konsumen.

\section{Pengertian Simpan Pinjam}

Simpan Pinjam adalah kegiatan untuk menghimpun dana yang disalurkan melalui kegiatan usaha simpan dari dan untuk koperasi yang bersangkutan, koperasi lain atau anggotanya. (Anonim Pengertian SimpanPinjam.http//www.thccli.com/doku men/) Kredit berasal dari bahasa yunani, yaitu "credere" atau "credo" yang berarti kepercayaan (trush atau faith). Kegiatan orang perorang atau badan usaha dalam rangka pemenuhan kebutuhan hidupnya dengan cara pinjam meminjam dinamakan kredit. Berdasar dari kegiatan pemberian kredit dari yang memberikan kredit kepada yang menerimanya. Dalam arti yang lebih luas pengertian kredit adalah kemampuan untuk melaksanakan suatu pemberian atau mengadakan suatu pinjaman dengan suatu janji pembayarannya akan dilakukan pada suatu jangka waktu yang disepakati.

\section{Pengertian Perkreditan (Pembagian Kredit )}

Perkreditan adalah penyerahan barang, jasa, atau hutang dari satu pihak (kreditor /atau pemberi pinjaman) atas dasar kepercayaan kepada pihak lain (nasabah atau pengutang/borrower) dengan janji membayar dari penerima kredit kepada pemberi kredit pada tanggal yang telah disepakati kedua belah pihak

\section{Pengertian Pegawai}

Pegawai adalah orang yang bekerja pada suatu instansi dan mendapatkan gaji setiap bulan. Hasibuan (2009:20), menyatakan bahwa pegawai adalah orang menjual jasa (pikiran dan tenaga) dan mendapat kompensasi (balas jasa) yang besarnya telah ditetapkan terlebih dahulu, dimana mereka wajib dan terikat untuk mengerjakan pekerjaan yang diberikan dan berhak memperoleh gaji sesuai dengan pinjaman.

Perbedaan antara Pegawai dan Karyawan, karyawan adalah pekerja dalam perusahaan dan seringkali berhubungan dengan masalah administrasi. Sedangkan pegawai umumnya adalah mereka yang bekerja di instansi pemerintahan alias pegawai negeri sipil.

Dari pembahasan di atas dapat disimpulkan bahwa, Primer Koperasi Kartika Babullah Kota Ternate berdiri dalam suatu instansi dan bukan berdiri sendiri seperti PT atau CV. Karena pegawainya merangkap tugas sebagai pegawai sekaligus menjadi pengurus anggota koperasi

\section{Basis Data (Database)}

Menurut Kadir A. (2000:56) Basis data (bahasa Inggris: database), atau sering pula dieja basisdata, adalah kumpulan informasi yang disimpan di dalam komputer secara sistematik sehingga dapat diperiksa menggunakan suatu program komputer untuk memperoleh informasi dari basis data 
tersebut. Perangkat lunak yang digunakan untuk mengelola dan memanggil kueri (query) basis data disebut sistem manajemen basis data (database management system, DBMS). Sistem basis data dipelajari dalam ilmu informasi

\section{Pengertian Delphi.}

Menurut Ingge (2002:13) Delphi adalah Suatu bahasa pemrograman yang menggunakan visualisasi sama seperti bahasa pemrograman Visual Basic (VB). Namun Delphi menggunakan bahasa yang hampir sama dengan pascal (sering disebut objeck pascal). Sehingga lebih mudah untuk digunakan. Bahasa pemrograman Delphi dikembangkan oleh Code Gear sebagai divisi pengembangan perangkat lunak milik embarcadero. Divisi tersebut awalnya milik borland, sehingga bahasa ini memiliki versi Borland Delphi. Delphi juga menggunakan konsep yang berorientasi objek (OOP) maksudnya pemrograman dengan membantu sebuah aplikasi yang mendekati keadaan dunia yang sesungguhnya. Awalnya bahasa pemrograman delphi hanya dapat digunakan di Microsoft Windows, namun saat ini telah dikembangkan sehingga dapat digunakan juga di Linux dan di Microsoft NET. Umumnya delphi hanya digunakan untuk pengembangan aplikasi dekstop, enterprise berbasis database dan program-program kecil. Namun karena pengembangan delphi yang semakin pesat dan bersifat general purpose bahasa pemrograman ini mampu digunakan untuk berbagai jenis pengembangan software. Dan Delphi juga disebut sebagai pelopor perkembangan RadTool ( Rapid Apllication Development ) tahun 1995. Sehingga banyak orang yang mulai mengenal dan menyukai bahasa pemrograman yang bersifat VCL (Visual component library) yang berisi kumpulan object yang ditulis dalam object pascal dari delphi untuk dipakai pada form delphi. Form merupakan inti dari setiap aplikasi delphi yang dapat dianggap sebagai sebuah window. Form dipakai untuk menempatkan komponen, kontrol, dll. Informasi mengenai form disimpan didalam dua file. ( $d f m$ dan fas). Adapun komponen- komponen delphi yang dipakai di dalam membuat program aplikasi antara lain :

1. Project, merupakan sekumpulan form,unit dan beberapa hal lain dalam program aplikasi. File utama project di simpan dalam file yang berakhiran.

2. Form, merupakan suatu yang dipakai sebagai tempat suatu program aplikasi form membentuk jendela dan dapat dibayangkan sebagai media tata letak dalam mengatur posisi item dari tampilan program.

3. Unit, adalah modul kode program. Suatu project mungkin mempunyai suatu unit atau lebih. Dalam delphi ada unit yang terpisah dari form yang disebut unit program.

\section{METODE PENELITIAN Jenis dan Sumber Data}

Jenis data yang digunakan dalam penelitian ini yaitu :

a. Data Primer, yaitu jenis data yang diperoleh langsung pada objek penelitian melalui wawancara langsung dengan pimpinan Primer Koperasi Kartika Babullah Kota Ternate.

b. Data Sekunder yaitu data yang berupa dokumen-dokumen atau laporanlaporan lainya yang relefan dengan penelitian ini. 


\section{Analisa sistem yang berjalan}

Sistem yang sedang berjalan di Primer Kopersi Kartika Babullah Kota Ternate masih menggunakan sistem pencatatan manual, dengan melalaui beberapa proses yaitu Pengambilan Formulir, persetujuan Kepala Seksi, persetujuan Bendahara dengan membawa slip gaji Terakhir, kemudian kembali ke Koperasi dengan membawa Formulir untuk disetujui, mencatat transaksi pinjaman dan transaksi pengembalian serta pencairan. Adapun sistem yang sedang berjalan pada Primer Koperasi Kartika Babullah Kota Ternate dapat dilihat pada gambar 1 berikut.

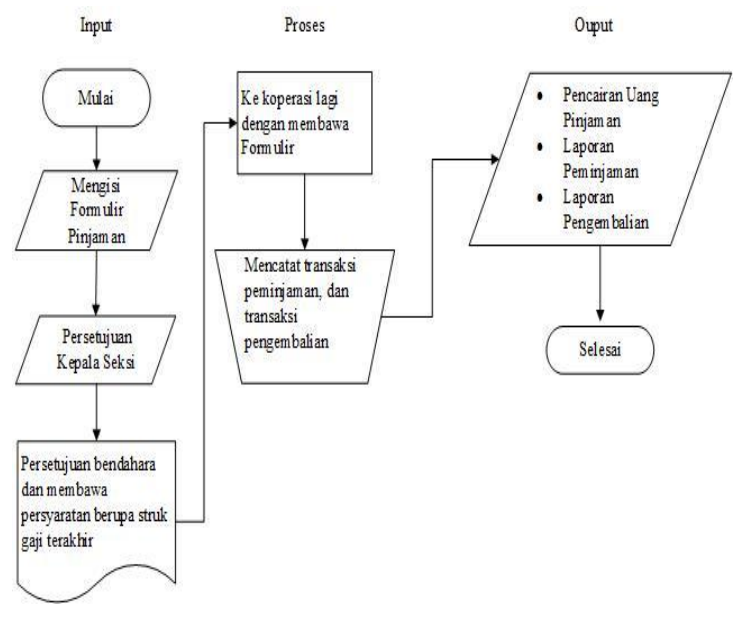

Gambar 1 : Sistem yang berjalan

Kelemahan - kelemahan yang terdapat dalam sistem yang sedang berjalan antara lain:

1. Para Anggota yang hanya mau mengetahui informasi sisa angsuran dengan cara berkunjung ke Koperasi tersebut.

2. Pengecekan data-data Koperasi masih membutuhkan waktu lama karena harus mengantri daan memeriksa secara manual.

3. Tingkat keamanan sistem penyimpanan data sangat rendah, karena buku dokumen menjadi arsip satu-satunya

\section{Analisys system yang di usulkan}

Untuk mengatasi berbagai permasalahan yang terdapat pada sistem yang sedang berjalan, maka pada bagian ini dikembangkan sistem berbasis Borland Delphi 7. Adapun sistem yang diusulkan dapat dilihat pada gambar 2 berikut

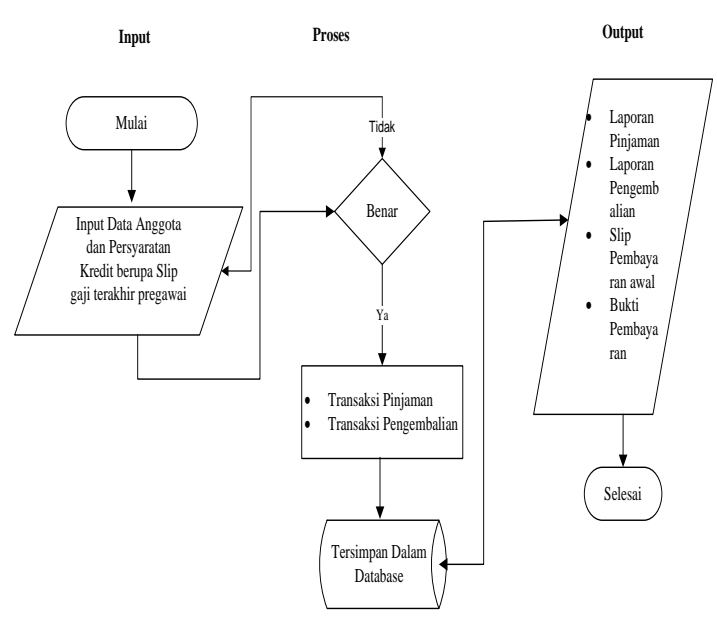

Gambar 2: Sistem yang diusulkan

\section{Bahan dan Alat}

Guna menunjang penelitian dalam pengembangan / perancangan sistem diusulkan, maka diperlukan bahan dan alat pendukung. Adapun bahan dan alat yang digunakan antara lain.

1. Perangkat Keras (Hardware)
a. Processor intel Atom.
b. Mainbord intel Atom.
c. RAM 2 GB.
d. Hardisk $500 \mathrm{~GB}$.
e. LCD Axioo 32 bit
f. Printer Cannon IP2700.

2. Perangkat Lunak (Software)

a. Sistem operasi windows 7 ultimate

b. Borland Delphi 7

c. Microsoft Office

d. Microsoft Visio 


\section{PERANCANGAN SISTEM}

Setelah mengetahui masalah yang sering dihadapi oleh pihak Primer Koperasi Kartika Babullah secara tepat, maka tugas selanjutnya adalah mendesain solusi sesuai dengan hasil analisis, Seperti membuat Flowchart dan rancangan menu program untuk memberikan gambaran yang jelas tentang kebutuhan yang diperlukan. Sistem informasi yang akan dibuat diharapkan mampu meningkatkan efektifitas dan efesiensi dalam mengelola perkreditan pegawai pada Primer Koperasi Kartika Babullah Kota Ternate

\section{Flowchart Login}

Flowchart merupakan diagram yang memperlihatkan sistem sebagai sebuah proses. Tujuaannya adalah memberikan pandangan umum sistem. Dari gambar berikut diperlihatkan hubungan dan interaksi atara admin dan sistem, gambar berikut merupakan gambaran interaksi antara pengguna dengan system pada Sistem Informasi Perkreditan Pegawai Pada Primer Koperasi Kartika Babullah Kota Ternate. Rancangan flowchart login dapat dilihat pada halaman berikut.

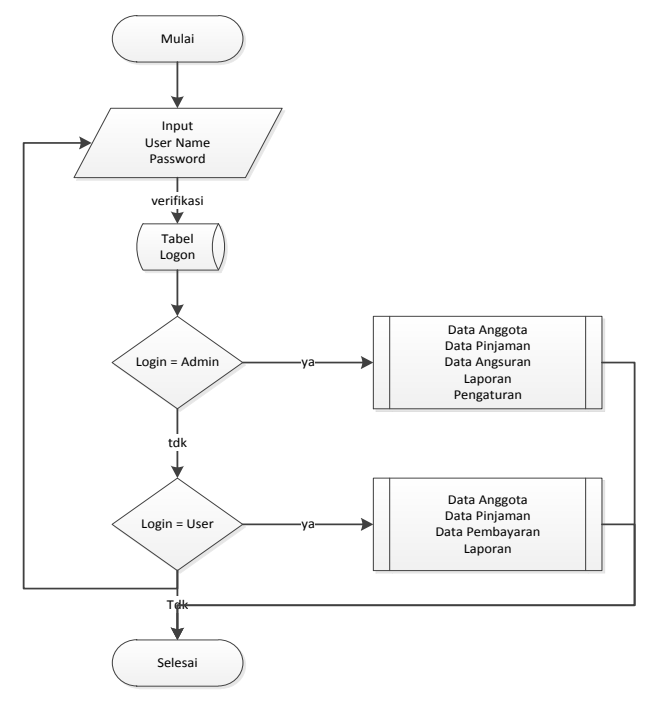

Gambar 3 : Flowchart Login
Berikut adalah keterangan dari gambar flowchart sistem login sebagai berikut:

1. Pengguna diminta oleh sistem untuk mengisi user name dan password

2. Sistem akan memverifikasi user name dan password yang dimasukkan oleh pengguna apakah terdapat dalam database atau tidak.

3. Jika user dan password terdapat dalam database selanjutnya sistem memverifikasi level user apakah sebagai admin ataukah sebagai user.

4. Jika level login sebagai admin maka seluruh menu pada program dapat di akses oleh pengguna, sedangkan apabila sebagai user maka khusus menu pengaturan yang tidak dapat di akses oleh user.

\section{Flowchart Data Anggota}

Flowchart data anggota merupakan langkah yang digunakan dalam merancang interaksi sistem dengan pengguna yang berhubungan dengan data anggota, adapun langkah-langkahnya dapat dilihat pada halaman berikutnya.

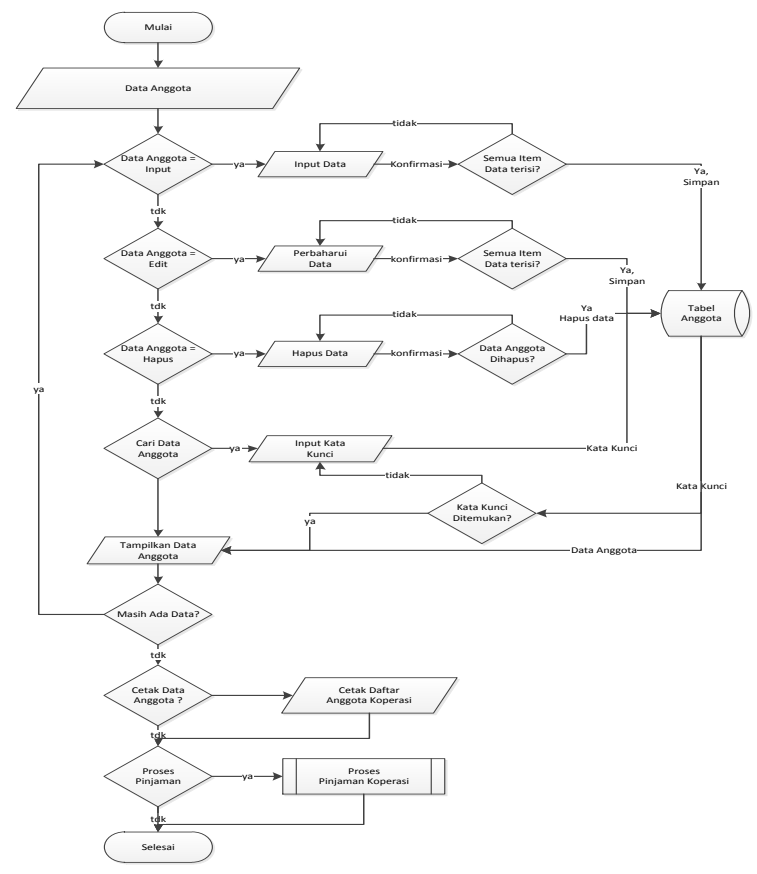

Gambar 4 : Flowchart Anggota 
1. Sistem, menampilkan data anggota dimana terdapat beberapa aksi yang dapat dilakukan oleh pengguna terhadap data anggota yang ditampilkan oleh sistem diantaranya input, edit, hapus, cetak data dan yang terakhir adalah proses data pinjaman.

2. Pengguna, memilih salah satu item pilihan yang disediakan oleh sistem sehingga sistem akan bekerja sesuai dengan item pilihan yang dipilih oleh pengguna. Misalnya pengguna memilih input data maka sistem akan menampilkan item-item data yang harus diisi oleh pengguna dan apabila semua item sudah diisi oleh pengguna selanjutnya sistem akan memverifikasi apakah semua item sudah terisi atau belum, jika terdapat salah satu saja item data tidak terisi maka sistem akan meminta pengguna untuk mengisi kembali item-item data yang tidak terisi sebelumnya dan jika sudah terisi semuanya selanjutnya sistem akan menyimpannya kedalam tabel database anggota. Begitupun untuk pilihanpilihan yang lainnya.

\section{Flowchart Data Pinjaman}

- Adapun rancangannya dapat dilihat pada gambar berikut.

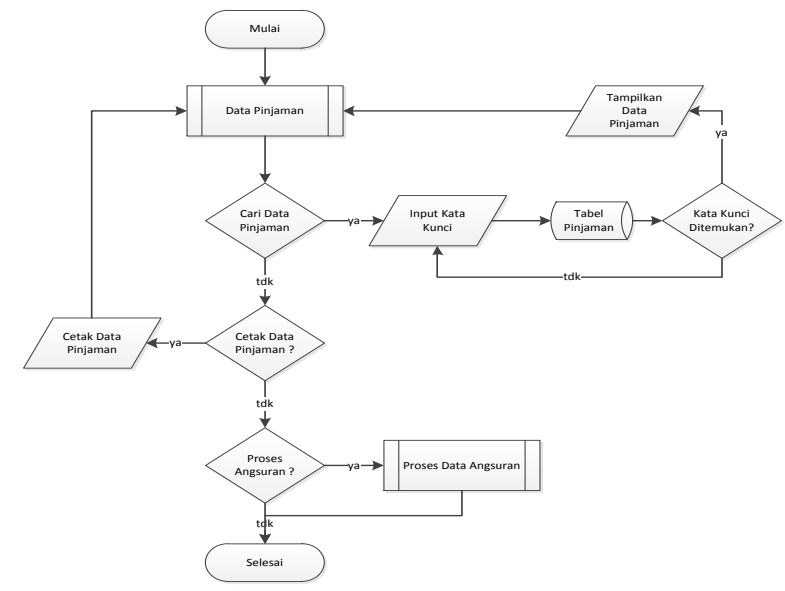

Gambar 5 : Flowchart Pinjamanan
1. Sistem, menampilkan data pinjaman yang sudah diproses sebelumnya, dimana terdapat beberapa aksi yang dapat dilakukan oleh pengguna terhadap data anggota yang ditampilkan oleh sistem diantaranya yakni pencarian data pinjaman anggota, proses pembayaran angsuran dan cetak data pinjaman anggota koperasi.

2. Pengguna, dapat memilih salah satu proses jika pengguna memilih proses pencarian data maka pengguna dapat memasukkan kata kunci yang dicari dan sistem akan menampilkan data dari kata kunci yang dicari, jika pengguna memilih proses cetak data pinjaman maka sistem akan menampilkan daftar data pinjaman yang siap untuk dicetak ke printer, dan yang terakhir apabila pengguna memilih melakukan proses pembayaran angsuran maka sistem akan menampilkan proses pembayaran angsuran pinjaman.

\section{Perancangan Tabel}

\section{Tabel Anggota}

Tabel 1 Tabel Anggota

\begin{tabular}{|l|l|l|}
\hline \multicolumn{2}{|c|}{$\begin{array}{l}\text { Field Name } \\
\text { anggota }\end{array}$} & \multicolumn{2}{c|}{ Data Type } & \\
\hline idreg & Text & Nomor Registrasi Anggota \\
\hline nama & Text & Nama Anggota \\
\hline alamat & Text & Alamat \\
\hline idn & Text & Jenis Identitas \\
\hline nmr & Text & Nomor Identitas \\
\hline call & Text & Nomor Telp Anggota \\
\hline
\end{tabular}

\section{Tabel Pinjam}

Tabel 2 : Pinjam

\begin{tabular}{|l|l|l|}
\hline \multicolumn{2}{c|}{\begin{tabular}{l}
\multicolumn{2}{c|}{ Dinjam } \\
\multicolumn{1}{|c|}{ Field Name }
\end{tabular}} & \\
\hline pinid & Text & Registrasi Pinjaman \\
\hline tanggal & Text & Tanggal Peminjaman \\
\hline idreg & Text & Nomor Registrasi Anggota \\
\hline Pinjaman & Currency & Jumlah Pinjaman \\
\hline Lama & Number & Lama Angsuran \\
\hline Angsuran & Currency & Angsuran Pinjaman \\
\hline Status & Text & Status Pinjaman \\
\hline
\end{tabular}


Tabel Angsuran

Tabel 3 Tabel Angsuran

\begin{tabular}{|c|c|c|}
\hline \multicolumn{3}{|l|}{ 困 angsuran } \\
\hline Field Name & Data Type & \\
\hline idang & Text & ID Angsuran \\
\hline tglsetor & Text & Tanggal Angsuran \\
\hline idreg & Text & Nomor Registrasi Anggota \\
\hline pinid & Text & Registrasi Pinjaman \\
\hline angsuran & Currency & Angsuran \\
\hline setor & Currency & Jumlah Setoran \\
\hline sisa & Currency & Sisa Angsuran \\
\hline ket & Text & Status Angsuran \\
\hline
\end{tabular}

Tabel Logon

Tabel 4 Logon

\begin{tabular}{|c|c|c|c|}
\hline \multicolumn{4}{|l|}{ 事 logon } \\
\hline & Field Name & DataType & \\
\hline 8 User & & Text & User/Pengguna \\
\hline passwd & & Text & Password User/Pengguna \\
\hline level & & Text & Level User \\
\hline
\end{tabular}

\section{Relasi Tabel (Relationship)}

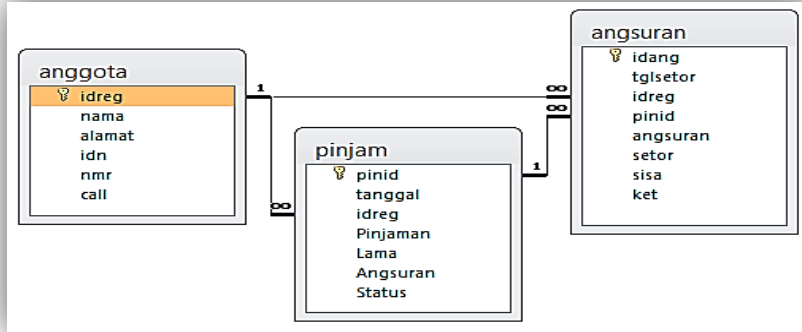

Gambar 6: Relasi Tabel

IMPLEMENTASI SISTEM

\section{Tempilan Halam Utama}

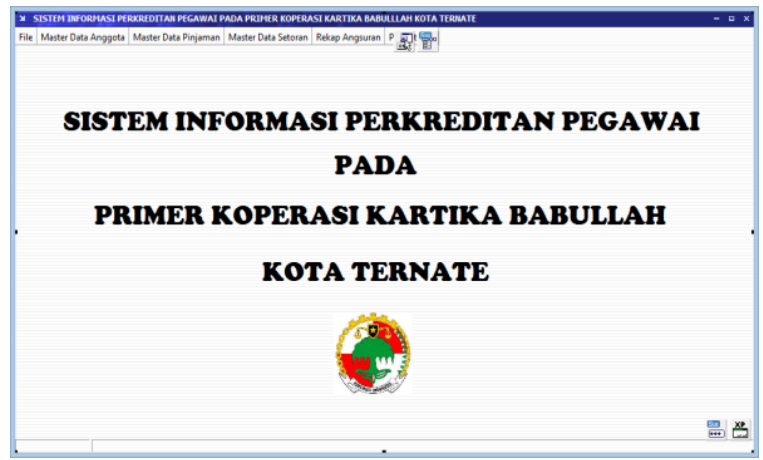

Gambar 7 : Halaman Utama

\section{Form Login}

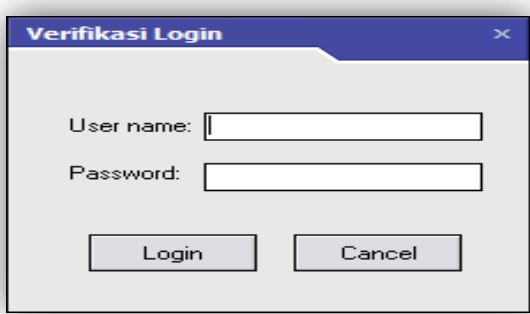

Gambar 8 : menu login

\section{Form Pinjaman}

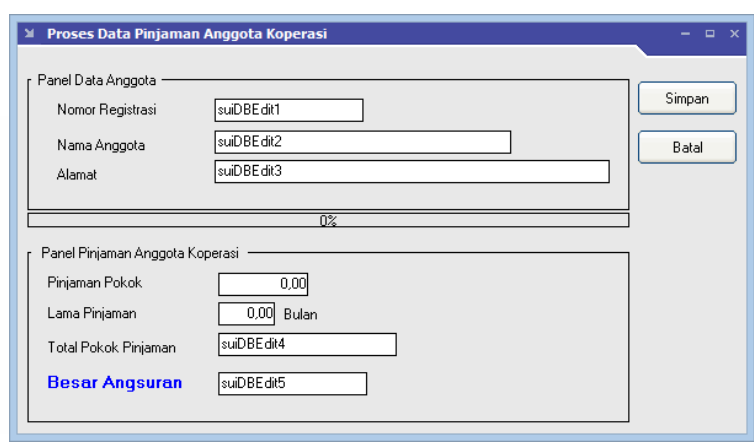

Gambar 9 : Form Pinjaman

\section{Form Pembayaran Angsuran}

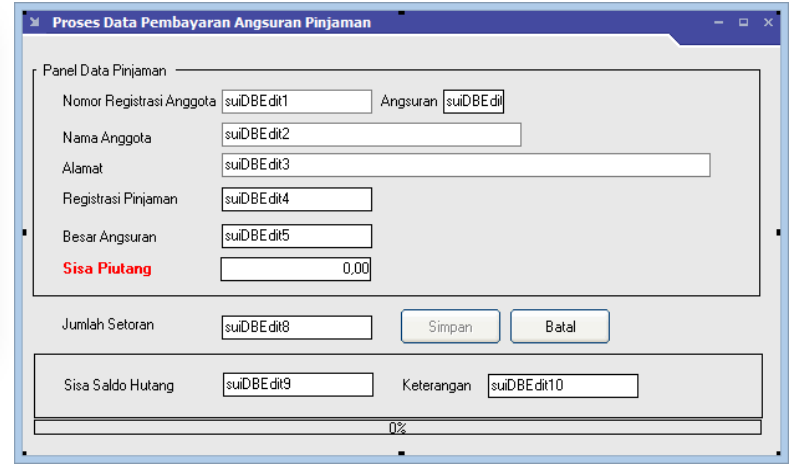

Gambar 10 : Form Pembayaran Angsuran

\section{Laporan Rekapitulasi Pinjaman dan}

\section{Angsuran}

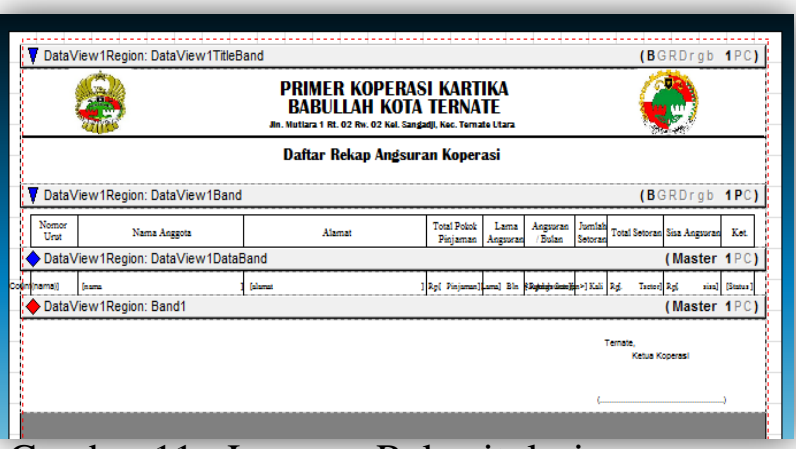

Gambar 11 : Laporan Rekapitulasi pinjaman dan angsuran 


\section{KESIMPULAN}

Setelah melakukan pembahasan dan pengkajian tentang pembuatan program Sistem Informasi Kredit Pegawai Pada Primer Koperasi Babullah Kota Ternate, dapat diambil kesimpulan sebagai berikut : 1. Setelah kami melakukan penelitian pada Primer Koperasi Kartikan Babullah Kota Ternate, dan sistem yang di gunakan pada Koperasi dalam melakukan peminjaman uang kepada nasabah masih menggunakan sistem secara manual, maka dengan adanya Aplikasi Borlan Delphi 7 yang telah dirancang dapat mempermudah sistem peminjaman kas secara kredit dengan cepat dan tepat. 2. Rancangan system informasi pinjaman kredit dalam bentuk software dengan menggunakan Borlan Delphi 7 yang mudah digunakan dan mempercepat proses kerja pegawai. Adapun saran sebagai berikut: Untuk lebih menyempurnakan sistem informasi pada Primer Koperasi Kartikan Babullah Kota Ternate maka diperlukan suatu sistem informasi yang mampu menyimpulkan, dan memproses data pinjaman uang pada anggota yang sistematis. Sistem informasi yang sistematis dapat terwujud jika data anggota diolah terintegrasi dalam Database, sehingga pengumpulan, penyimpanan dan pemprosesan lebih mudah, cepat, akurat serta efektif dan efisien. 1. Karena program aplikasi ini masih mempunyai kekurangan oleh karena itu mahasiswa yang bergelut dalam bidang teknologi informasi dan pemograman agar menyempurnakan program ini menjadi lebih baik dan sempurna. 2. Untuk pegawai koperasi harus bisa mengoperasikan berbagai aplikasi perangkat lunak.

\section{DAFTAR PUSTAKA}

Kadir, 2000, Basis Data, Printice Hall International.Yogyakarta.

Ingge, 2002, Pengertian Delphi, PT. Eleks Media Compotindo. Jakarta.

Anonim Pengertian Simpan Pinjam. http//www.thccli.com/ dokumen/.

Jogiyanto, 2005, Pengertian Sistem, Andi Offset.Yogyakarta.

Samuelson, 2005, Pengertian Koperasi, Fakultas Ekonomi Universitas Indonesia. Jakarta.

Teddy Marcus Zakaria, 2006, Pengertian Struktur Data, Informatika. Bandung.

Azar Susanto, 2007, Pengertian Sistem informasi, Pionir Jaya.Jakarta.

Kusrini, 2007, Pengertian Informasi,Unit Penerbit Percetakan STIM YKPN. Yogyakarta.

McLeod, 2007, Pengertian Perancangan Sistem Informasi, PT. Intermasa. Jakarta

Hasibuan, 2009, Pengertian Pegawai, Andi Offset. Yogyakarta.

Sayid Syekh, 2011, Pengertian Data, PT. Eleks Media Compotindo. Jakarta.

Hartono, 2013, Pengertian Sistem, Rineka Cipta. Jakarta.

Anis Nurhanafi, Sistem Informasi Simpan Pinjam Pada Koperasi Sari Mulyo Kecamatan Ngadirojo, IJNS Indonesian Journal on Networking and Security - Volume 3 No 3 - Juli 2014 - ijns.org, ISSN: 2302-5700 (Print) 2354-6654 (Online)

Yonatan Liliek Prihartanto (2013), Sistem Informasi Manajemen Agenda Pada Badan Pelayanan Perijinan Terpadu Kabupaten Karanganyar, Indonesian Jurnal on Computer Science - Speed (IJCSS) 15 FTI UNSA Vol 10 No 1 - Februari 2012 - ijcss.unsa.ac.id, ISSN $1979-9330$ 